\title{
Prawa dziecka \\ w prawie polskim - \\ wybrane zagadnienia
}

Osobie ludzkiej przypisane są prawa charakteryzujące się tym, iż dotyczą każdego człowieka niezależnie od płci, wieku, stanu zdrowia, systemu politycznego czy ekonomicznego, w jakim żyje, wreszcie od wyznawanej religii. Prawa osoby ludzkiej winny leżeć u podstaw systemu prawa stanowionego, bowiem wszędzie tam, gdzie prawa te są naruszane przez prawo stanowione, można mówić o swego rodzaju (większym lub mniejszym) totalitaryzmie, nawet jeżeli system polityczny określany jest jako demokracja. Wspomniane zostało, iż prawa osoby ludzkiej przynależą każdemu bez względu na wiek czy płeć, a zatem również dziecku', niezależnie od tego, czy dziecko jest wychowywane przez obydwoje rodziców, czy przez jedno z nich, czy też nie ma rodziców i jest wychowywane jedynie przez instytucje państwowe. „Dziecko pozbawione opieki rodzicielskiej ma prawo do opieki i pomocy władz publicznych”2 stanowi Konstytucja Rzeczypospolitej Polskiej.

1 Por. J. Adolphe, A light to the nations: The Holy See and Convention on the rights of the child, Rome 2003, s. 21.

2 Por. Konstytucja Rzeczypospolitej Polskiej z dnia 2 kwietnia 1997 r. (Dz.U. $\mathrm{Nr} 78$, poz. 483 z późn. zm.), art. 72.2 [dalej: KRP]. 
Termin „konstytucja” ma swoje źródło w języku łacińskim i słowie constituere czyli „ustanawiać, urządzać” , a zatem chodzi tu między innymi o urządzenie i zorganizowanie państwa, nadanie mu ustroju politycznego ${ }^{3}$ i ochronę praw osoby ludzkiej, w tym dziecka.

Zarówno rodzice, jak i wspomniane instytucje winny przestrzegać praw dziecka. W rozumieniu polskiego prawa dzieckiem jest każdy człowiek od poczęcia do momentu, w którym osiąga pełnoletność ${ }^{4}$. To niezwykle istotna definicja, pozwalająca na wyraźne stwierdzenie, iż człowiek, a więc dziecko, pojawia się w momencie poczęcia. Poniższy artykuł stanowi próbę analizy wybranych przez autora praw dziecka w oparciu o wybrane przepisy prawa stanowionego. Z racji objętości artykułu nie sposób bowiem przywołać wszystkich praw, jakie przysługują dziecku, jak również wszystkich przepisów prawa odnośnie do opisanych tu praw dziecka.

Chcąc jednak dokonać wspomnianego omówienia, należy na początku omówić po krótce źródła praw osoby ludzkiej.

\section{1. Źródła praw osoby ludzkiej}

Człowiek jest istotą wolną oraz rozumną, co sprawia, iż może podejmować w swoim życiu konkretne decyzje w oparciu o racjonalną ocenę rzeczywistości. Tak jak wolna wola i rozum są wpisane w osobę ludzką, tak również przynależy jej niezbywalna godność, która łączy się z człowieczeństwem. To właśnie godność leży u podstaw równości wszystkich osób ${ }^{5}$ względem siebie. Godność, jak zostało powiedziane, ma charakter trwały, niezależny od

3 Por. F. Siemieński, Prawo konstytucyjne, Warszawa-Poznań 1980, s. 14.

4 Por. Ustawa o Rzeczniku Praw Dziecka z dnia 6 stycznia 2000 r. (Dz.U. Nr 6, poz. 69 z późn. zm.), art. 2.1 [dalej: UoRPD].

5 Por. F. J. Mazurek, Godność osoby ludzkiej podstawa praw człowieka, Lublin 2001, s. 21. 
okoliczności zewnętrznych, a zatem system prawny czy polityczny nie może odebrać człowiekowi godności. Z godności osoby ludzkiej wypływają prawa, a każde z nich ma takie samo znaczenie i żadnego nie można człowieka pozbawić. Pierwszym elementarnym prawem jest prawo do życia, następnie prawo do wychowania, a tym samym również wykształcenia, prawo do ochrony zdrowia, prawo do wolności religijnej oraz wolności sumienia, prawo do posiadania majątku, prawo do wyboru drogi życiowej. Jak zostało wspomniane wcześniej, prawa te dotyczą również dziecka, a Konstytucja Rzeczypospolitej Polskiej z dnia 2 kwietnia 1997 roku stoi na straży tych praw, stanowiąc: „Rzeczpospolita Polska zapewnia ochronę praw dziecka. Każdy ma prawo żądać od organów władzy publicznej ochrony dziecka przed przemocą, okrucieństwem, wyzyskiem i demoralizacją" (art. 72 ust. 1). Należy zwrócić uwagę, iż w kontekście ochrony praw dziecka ustawodawca nakazał władzy publicznej ochronę dziecka przed negatywnymi czynnikami jakie mogącymi mieć wpływ na jego życie, w tym demoralizacją. Ochrona praw dziecka jest ujęta w Ustawie Zasadniczej, warunkując potrzebę ochrony praw dziecka w pozostałych aktach prawnych, jak również w funkcjonowaniu instytucji państwa. Tym samym godność osoby ludzkiej i jej prawa wpisane w człowieka znajdują swoje odzwierciedlenie w prawie stanowionym. Podstawowe prawa człowieka chronione są na polu międzynarodowym. Polska będąca członkiem ONZ i sygnatariuszem Karty Narodów Zjednoczonych jednocześnie przyjęła i zobowiązała się do przestrzegania zapisów wyżej wymienionej Karty. I tak już w części wstępnej Karty odnajdujemy zapis mówiący i potwierdzający wiarę w prawa człowieka, jego godność, jak również wartość osoby ludzkiej. Prawa te są

6 Por. Z. Resich, Międzynarodowa ochrona praw człowieka, Warszawa 1981, s. 30 . 
chronione przez Ogólne Zgromadzenie, Radę Gospodarczą oraz Radę Powierniczą. Wespół z tymi organami należącymi do głównych organów ONZ działają również organy pomocnicze, takie jak Komisja Praw Człowieka powstała 15 lutego 1945 roku7, czyli jeszcze przed zakończeniem II wojny światowej, która trwając sześć lat, była polem łamania praw człowieka. Ochrona poszczególnych praw człowieka dotyczy różnej „kategorii” osób, w tym dzieci.

Nie sposób nie przywołać tutaj Powszechnej Deklaracji Praw Człowieka, stwierdzającej, iż zarówno matka, jak i dziecko mają specjalne prawo do pomocy oraz opieki, a każde dziecko, niezależnie od tego, czy jest ono dzieckiem małżeńskim, czy też pozamałżeńskim, ma identyczną ochronę o charakterze społecznym8. „Każdy człowiek ma prawo do korzystania ze wszystkich praw i wolności proklamowanych w niniejszej Deklaracji bez względu na różnice rasy, koloru, płci, języka, wyznania, poglądów politycznych i innych, narodowości, pochodzenia społecznego, majątku urodzenia lub jakiejkolwiek różnicy. Nie wolno ponadto czynić żadnej różnicy w zależności od sytuacji politycznej, prawnej, międzynarodowej kraju lub obszaru, do którego dana osoba przynależy, bez względu na to, czy dany kraj lub obszar jest niepodległy, czy podlega systemowi powiernictwa, czy rządzi się samodzielnie, czy też jest w jakikolwiek sposób ograniczony w swej niepodległości”. W powyższej regulacji wysunięta zostaje potrzeba zapewnienia przez systemy prawne poszczególnych państw odpowiedniego prawa gwarantującego opiekę i pomoc. Co więcej, nie

7 Por. Z. Resich, Międzynarodowa ochrona praw człowieka, dz. cyt., s. 31.

8 Powszechna Deklaracja Praw Człowieka (uchwalona przez Zgromadzenie Ogólne ONZ 10.12.1948), art. 25, [w:] Prawa człowieka w systemie kapitalistycznym, red. M. Wasilewski, Warszawa 1979, s. 27.

9 Por. Powszechna Deklaracja Praw Człowieka, art. 2. 
istnieje rozróżnienie na dzieci, które urodziły się w małżeństwie, i te, które przyszły na świat poza nim. Przepis ten dotyczy również dzieci, których rodzice zmarli lub zostali pozbawieni władzy rodzicielskiej bądź posiadają ograniczoną władzę rodzicielska. Żadne dziecko nie może być dyskryminowane przez system prawa, system gospodarczy ze względu na swoje pochodzenie, wyznawana religię etc. Ewidentnym pogwałceniem tego prawa było w PRL dodawanie punktów na egzaminach wstępnych na uczelnie wyższe ze względu na pochodzenie robotnicze.

W tym miejscu wydaje się słuszne przeanalizowanie wybranych praw dziecka, rozpoczynając od prawa najbardziej elementarnego, czyli prawa do życia.

\section{Prawo do życia jako podstawowe prawo dziecka}

Jeżeli mówimy o ochronie życia każdego dziecka, należy podkreślić, iż dotyczy ona ochrony także dziecka poczętego, ale nienarodzonego, co związane jest z całkowitym zakazem aborcji w niektórych systemach prawnych, bądź jej częściową dopuszczalnością, jak ma to miejsce w polskim prawie, lub całkowitą legalnością, jak to de facto miało miejsce w PRL-u, gdzie kobieta mogła usunąć ciążę ze względu na trudne warunki życia. Międzynarodowy Pakt Praw Obywatelskich i Politycznych stanowi, że każdy człowiek ma prawo do życia, które to prawo ma charakter przyrodzony i winno być chronione przez ustawę, a więc prawo do życia jest podstawowym prawem każdego człowieka. Aby w szczególny sposób to prawo chronić, powinno ono mieć charakter ustawowy. W sposób dorozumiany jest ono chronione

10 Międzynarodowy pakt Praw Obywatelskich i Politycznych (uchwalony przez Zgromadzenie Ogólne ONZ 16.12.1966), art. 6, [w:] Prawa człowieka w systemie kapitalistycznym, dz. cyt., s. 37. 
w ustawie przywołanej już wyżej, a stanowiącej, że dzieckiem jest istotą ludzką od chwili poczęcia do momentu, kiedy osiągnie pełnoletność (art. 2, ust. 1). Ta pochodząca z 2000 roku regulacja jest jednym z punktów wyjścia do ochrony życia dzieci nienarodzonych; co więcej, daje im do tej ochrony prawo, poza trzema wyjątkami zawartymi w Ustawie o planowaniu rodziny, ochronie płodu ludzkiego i warunkach przerywania ciąży z 7 stycznia 1993 roku, która dopuszcza prawo przerwania ciąży, jeżeli jest ona zagrożeniem dla życia bądź zdrowia matki, jeśli badania prenatalne lub też inne przesłanki o charakterze medycznym potwierdzą duże prawdopodobieństwo trwałego i ciężkiego upośledzenia dziecka poczętego bądź choroby, która jest nieuleczalna, a która zagraża jego życiu, oraz w trzecim wypadku - jeżeli istnieje uzasadnione podejrzenie, że ciąża jest skutkiem czynu zabronionego" ${ }^{11}$. W pierwszym wypadku prawo do życia dziecka zostało „zestawione” z prawem do życia kobiety oraz z zagrożeniem jej zdrowia, w drugim z chorobą lub upośledzeniem płodu, w trzecim z poczęciem, które jest wynikiem czynu zabronionego. W obiegowej opinii funkcjonuje przekonanie, iż ustawodawca dopuścił możliwość przerwania ciąży, jeżeli jest ona wynikiem gwałtu - należy podkreślić, iż czyn zabroniony ma szerszy zakres niż gwałt. Prawo wprowadza także wymogi dotyczące czasu przerwania ciąży. Są one inne w przypadku kwestii kryminalnych, inne w przypadku spraw eugenicznych i wskazań medycznych ${ }^{12}$. Przywołana wcześniej Ustawa o planowaniu rodziny, ochronie płodu ludzkiego i warunkach przerywania ciąży stanowi

11 Ustawa o planowaniu rodziny, ochronie płodu ludzkiego i warunkach przerywania ciąży z dnia 7 stycznia 1993 (Dz.U. 1993r. Nr 17, poz. 78 z późn. zm.).

12 Por. K. Wiak, Ochrona dziecka poczętego w polskim prawie karnym, Lublin 2001, s. $244-245$. 
kompromis pomiędzy środowiskami liberalnymi (postkomunistycznymi) a środowiskami konserwatywnymi. Pojawiają się jednak głosy, szczególnie ze strony reprezentantów silnych nurtów postmodernistycznych charakteryzujących się próbą całkowitej liberalizacji moralności, aby zmienić zapisy tej ustawy w celu jej liberalizacji.

W przywołanym powyżej pierwszym i zasadniczym prawie człowieka do życia nasuwa się refleksja dotycząca systemu prawa, który powinien być oceniany w oparciu o wolność oraz sprawiedliwośćn ${ }^{13}$. Tę ostatnią rozumiemy jako oddanie tego, co się komuś należy, a zatem każdy człowiek, w tym dziecko, ma prawo do życia od momentu naturalnego poczęcia do chwili naturalnej śmierci. Żaden system prawa stanowionego nie może odebrać dziecku tego elementarnego prawa, jeżeli tak się dzieje, ów system prawny jest krzywdzący i niesprawiedliwy. W tym miejscu warto zauważyć, czy właściwie jedynie wspomnieć, iż jeden z najbardziej liberalnych systemów prawnych dotyczących aborcji występuje w Holandiii"

Obok prawa do życia ważną rolę w życiu dziecka stanowi prawo do kształcenia, będące częścią prawa do wychowania. Obecnie w polskiej rzeczywistości dzieci spotykają się z coraz większymi problemami związanymi z możliwością zdobywania wiedzy, a wypływającymi z coraz gorszej sytuacji materialnej ich rodziców.

\section{Prawo do kształcenia jako element prawa do wychowania}

Niezwykle istotne w odniesieniu do praw dziecka jest prawo do zdobywania wiedzy, czyli możliwość kształcenia się, które w życiu

13 Por. H. Jankowski, Prawo i moralność, Warszawa 1968, s. 138.

14 Por. M. Korzewski, O tolerancji $w$ spoteczeństwie i prawie holenderskim, Kraków 2005, s. 247. 
osoby ludzkiej odgrywa ważną rolę i jest związane z wychowaniem. Prawo to odnosi się przede wszystkim do państwa, rodziny, ,jednakże jego realizacja jest uzależniona od wielu czynników, np. charakteru i stopnia powiązania podmiotu wychowywanego i wychowującego, wieku podmiotu wychowywanego i osiągniętego przez niego rozwoju. To wszystko ma wpływ na kształt i zakres regulacji prawnych procesu wychowania”"15. Inne obowiązki wychowawcze leżą po stronie rodziców wobec dziecka w wieku przedszkolnym, nieco inne wobec dziecka w wieku dorastania, czyli szkolnym. Dostrzegamy tutaj istotną kwestię związaną z prawem dziecka do kształcenia.

Prawo to jest zapisane w wielu aktach prawnych, w tym w Konstytucji Rzeczypospolitej Polskiej, która stanowi, iż każdy człowiek ma prawo do nauki - obowiązkowej do 18 roku życia, a nauka w szkołach publicznych ma charakter bezpłatny (art. 70 ust. 1, art. 70 ust. 2). Z punktu widzenia polskiego prawa obowiązek zapewnienia możliwości kształcenia dziecka leży po stronie państwa, jak również po stronie rodziców, którzy mają przyczyniać się do zaspokojenia potrzeb rodziny ${ }^{16}$ - zarówno potrzeb o charakterze materialnym, jak i tych związanych z rozwojem edukacyjnym dziecka. Dotyczy to nie tylko małżonków pozostających we wspólnym pożyciu, ale także tych, wobec których sąd orzekł rozwód, jak również i rodziców, którzy nie mają pełnej zdolności do czynności prawnych $^{17}$. Polski system prawa przyznaje rodzicom nadrzędną rolę

15 Por. P. Kroczek, Wychowanie. Optyka prawa polskiego i prawa kanonicznego, Kraków 2013, s. 28.

16 Por. Ustawa z dnia 23 kwietnia 1964 r. Kodeks cywilny (Dz.U. Nr 16, poz. 93 z późn. zm.), art. 28 [dalej: kc].

17 P. Kroczek, Wychowanie. Optyka prawa polskiego i prawa kanonicznego, dz. cyt., s. 31 . 
w wychowaniu dzieciir ${ }^{18}$ a zatem także w kształceniu, tym samym doceniając ich związek z dzieckiem i prawo dziecka do kształcenia według systemu wartości najbliższych, chociaż prawo to bywa ograniczane, o czym będzie mowa poniżej.

W kontekście wychowania dziecka pojawia się obowiązek alimentacyjny. „Prawo rodzinne przewiduje sytuacje, w których obowiązki alimentacyjne względem dziecka spoczywają również na tych rodzicach, którzy nie sprawują władzy rodzicielskiej, gdyż jej nigdy nie sprawowali (na przykład mężczyźni, których ojcostwo sądownie ustalono, lecz nie przyznano im władzy rodzicielskiej) lub którym ją odebrano”ㄹ. Alimenty związane są nie tylko z zapewnieniem podstawowego funkcjonowania dziecka, takiego jak jedzenie czy ubiór, ale także odnoszą się do kwestii związanych z kształceniem dziecka, nie tylko w szkole, ale również poza nią. Chodzi tutaj o konieczność zapewnienia korepetycji czy zajęć dodatkowych, których uczeń nie może realizować w szkole.

Głównym miejscem zdobywania wiedzy jest właśnie szkoła, w której uczniowi przysługują prawa w oparciu o przepisy prawa ogólnego, jak również statut szkoły ${ }^{20}$. Należy jednak podkreślić, iż prawa owe niekiedy są zbyt szerokie i niewspółmierne do obowiązków ucznia, jak również do praw nauczyciela względem ucznia. Takie zbyt liberalne traktowanie dziecka przez polski system szkolnictwa, zezwalanie mu na różne zachowania niekoniecznie ma charakter wychowawczy. Prawo do zdobywania wiedzy jest związane także z wychowaniem, bez którego młody człowiek nie jest w stanie funkcjonować w prawidłowy

18 Por. P. Kroczek, Wychowanie. Optyka prawa polskiego i prawa kanonicznego, dz. cyt., s. 51.

19 M. Andrzejewski, Prawo rodzinne i opiekuńcze, Warszawa 2010, s. 210.

20 Por. E. Socha, Prawa ucznia we współczesnej szkole, [w:] Prawa dziecka. Wybrane aspekty, red. I. Marczykowskai in., Rzeszów 2006, s. 116. 
sposób w relacjach z innymi. Nie można jednak mówić o odpowiednim wykształceniu i wychowaniu dziecka w kontekście zbyt licznych klas czy też coraz mniejszych wymagań, jeżeli chodzi o wiedzę, a przecież nauczyciel powinien kształtować postawy ucznia, stwarzać mu odpowiednie środowisko pracy i nawiązywać z nim kontakt osobowy, jednocześnie będąc wzorem dla dziecka ${ }^{21}$. Wówczas państwo będzie w odpowiedni sposób wypełniało względem dziecka prawo do kształcenia, nigdy bowiem kształcenie nie może być oddzielone od wychowania. Jednak państwo ogranicza rodziców w kwestiach edukacji. Chodzi tu między innymi o takie kwestie jak prawo do nauczania indywidualnego czy prawo do nauki poza szkołą, w których rodzice muszą uzyskać zgodę dyrektora szkoły do realizacji tych praw ${ }^{22}$. „Ten przykład obrazuje, jak państwo uzurpuje sobie kompetencje rodziców. Ustawodawca państwowy spycha rodziców do roli wykonawców swojej woli. Nie rodzice bowiem, lecz organy władzy państwowej i administracji publicznej, opierając się na regulacjach prawnych, decydują o tym aspekcie życia dziecka. Możliwość wyboru przez rodziców najlepszych według nich rozwiązań edukacyjnych dla dzieci jest ograniczona, bo obwarowana warunkami trudnymi do wypełnienia lub też uzależniona od decyzji urzędników. Można powiedzieć, że jest to zmniejszanie zakresu praw rodzicielskich związanych z władzą rodzicielską"²3.

Z drugiej strony państwo w oparciu o prawo ucznia do kształcenia zapewnia mu dojazd do szkoły. I tak Ustawa o systemie oświaty stanowi o obowiązku szkolnym polegającym na uczęszczaniu

21 Por. J. Homplewicz, Polskie prawo szkolne. Zagadnienia podstawowe, Warszawa 1984, s. 160.

22 Por. P. Kroczek, Wychowanie. Optyka prawa polskiego i prawa kanonicznego, dz. cyt., s. 52.

23 P. Kroczek, Wychowanie. Optyka prawa polskiego i prawa kanonicznego, dz. cyt., s. 52, 53 . 
dziecka do szkoły bądź publicznej, bądź też prywatnej²4 (realizacja przepisów Konstytucji). Dla dzieci, których droga do szkoły jest dłuższa niż $3 \mathrm{~km}$ (dzieci w klasach I-IV) lub dłuższa niż 4 km (w przypadku dzieci w klasach V-VI oraz młodzieży gimnazjalnej) gmina ma obowiązek zapewniania bezpłatnego transportu do szkoły, jeżeli dziecko nie ma możliwości korzystania z komunikacji publicznej (art. 17 ust. 2). Powyższe przepisy wskazują, iż wykształcenie jest nie tylko związane z budynkiem szkoły, ale także możliwością dotarcia do niego.

Prawo do kształcenia winno obejmować wszystkie dzieci, także niepełnosprawne fizycznie bądź intelektualnie. W polskim prawie istnieją przepisy stanowiące o prawie do nauki osób niepełnosprawnych, podobnie jak pełnosprawnych, i tworzeniu dla nich specjalnych szkół. Taka regulacja wypływa z zasady równości każdej osoby wobec prawa, jak również stąd, iż prawa człowieka przynależne są każdemu, o czym była mowa wyżej. Żadne dziecko nie może być dyskryminowane ze względu na swój wiek, pochodzenie czy chorobę. Obowiązkiem państwa jest chronić w szczególny sposób prawa do edukacji wśród osób niepełnosprawnych i dostosować jej poziom do ich możliwości fizycznych oraz intelektualnych. Obok prawa do kształcenia warto zwrócić uwagę także na prawo do posiadania, a w jego obrębie na prawo do dziedziczenia, jakie przysługuje dziecku.

\section{Prawo do dziedziczenia jako część prawa majątkowego}

Z praw człowieka wypływa prawo do posiadania rzeczy materialnych, a w kontekście dziecka warto spojrzeć na jego prawo

24 Por. Ustawa o systemie oświaty z dnia 7 września 1991 (Dz.U. Nr 56, poz. $458 \mathrm{z}$ późn. zm.), art. 15 . 
związane z dziedziczeniem. Kodeks cywilny stanowi, iż „w pierwszej kolejności powołane są z ustawy do spadku dzieci spadkodawcy oraz jego małżonek" (art. 931 k.c.). Dziecko ma prawo do dziedziczenia niezależnie od wieku, także wówczas gdy poczęło się, a jeszcze się nie urodziło. Taka sytuacja ma miejsce na przykład gdy podczas ciąży matki umiera ojciec dziecka, wówczas dziecko ma prawo do dziedziczenia po urodzeniu. A zatem prawo do dziedziczenia jest zapewnione przez polski system prawny dziecku nienarodzonemu, a poczętemu. Sprawiedliwość w kontekście dziedziczenia polega na tym, iż jako pierwsza dziedziczy najbliższa rodzina, następnie dalsza, a jeżeli jej nie ma, wówczas gmina, na terenie której znajdowało się ostatnie miejsce zamieszkania spadkodawcy, lub też Skarb Państwa ${ }^{25}$. Warto zwrócić uwagę, że jako ostatnie mają prawo dziedziczenia organ samorządowy i Państwo.

Z pierwszeństwem w dziedziczeniu, jakie przypada między innymi dzieciom spadkodawcy, związana jest wyjątkowa relacja i bliskość oparta na przykład na więzach krwi (choć nie tylko), obowiązkach rodziców wobec dzieci czy wreszcie odpowiedzialności za nie. Istotne jest to, iż „obecnie uprawnienie do dziedziczenia z ustawy może wynikać nie tylko ze stosunku małżeństwa, pokrewieństwa czy przysposobienia ze spadkodawcą, ale także stosunku powinowactwa istniejącego między spadkodawcą a dziećmi jego małżonka" ${ }^{26}$, przepisy te zostały wprowadzone w roku 2009. Prawo do dziedziczenia dziecka stanowi istotny

25 Por. Uzasadnienie wyroku TK z 4 września 2007 r., P19/o7, OTK-A 2007, $\mathrm{Nr}$ 8, poz. 94 .

26 Por. H. Witczak, Nowe zasady dziedziczenia ustawowego członków rodziny spadkodawcy, [w:] Prawo rodzinne w dobie przemian, red. P. Kasprzyk, P. Wiśniewski, Lublin 2009, s. 231. 
element sprawiedliwości społecznej wypływającej z docenienia relacji rodzinnych, a tym samym wskazania na rodzinę jako najmniejszą komórkę społeczną.

Obok prawa do dziedziczenia istotne ze względu na odpowiedni rozwój emocjonalny, ale i kształtowanie moralne, jest prawo do zamieszkania razem $\mathrm{z}$ rodzicami.

\section{Prawo do zamieszkania dzieci z rodzicami}

Prawo dziecka do życia rodzinnego charakteryzuje się przede wszystkim wspólnym zamieszkaniem dzieci z rodzicami, budowaniem relacji między członkami rodziny. Europejski Trybunał Praw Człowieka orzekł w 2005 roku, iż państwo ma obowiązek zabezpieczyć relacje rodzinne pomiędzy poszczególnymi członkami rodziny ${ }^{27}$. Problem z relacjami rodzinnymi pojawia się najczęściej w momencie, kiedy dzieci zamieszkują z jednym z rodziców po orzeczeniu przez sąd rozwodu. Wówczas może dochodzić do prób ograniczenia przez jedną ze stron kontaktów dzieci z byłym małżonkiem. Należy podkreślić, iż w normalnych relacjach takie kontakty są niezbędne i stanowią o podtrzymywaniu więzi między dzieckiem a rodzicem, a jednocześnie są realizacją obowiązku wychowawczego rodziców, bowiem prawo dziecka do utrzymywania kontaktu z rodzicami stanowi dla nich obowiązek. „Niezależnie od władzy rodzicielskiej rodzice oraz ich dziecko mają prawo i obowiązek utrzymywania ze sobą kontaktów. Kontakty z dzieckiem obejmują w szczególności przebywanie z dzieckiem (odwiedziny, spotkania, zabieranie dziecka poza miejsce jego stałego pobytu) i bezpośrednie

27 ETPC, Orzeczenie z dnia 23 czerwca 2005, skarga nr 48542/99, Sprawa Zawadka przeciw Polsce, ms.gov.pl/pl/orzeczenia-etpcz/download,159,o.html (12.01.2105). 
porozumiewanie się, utrzymywanie korespondencji, korzystanie z innych środków porozumiewania się na odległość, w tym ze środków komunikacji elektronicznej" (art. 113 k.r.o. ${ }^{28}$ ). Widać zatem, że Kodeks rodzinny i opiekuńczy dzieli kontakty między dziećmi a rodzicami na dwa rodzaje: są to kontakty bezpośrednie i osobiste, jak odwiedziny czy spotkania, z drugiej strony są to kontakty za pośrednictwem korespondencji czy też komunikacji elektronicznej. Ta ostatnia cieszy się coraz większą popularnością ze względu na fakt coraz bardziej ograniczonych osobistych kontaktów z rodzicami spowodowanych rosnąca liczbą rodziców pracujących poza granicami Polski. W tym kontekście należy powrócić do orzeczenia Europejskiego Trybunału Praw Człowieka i zadać pytanie, czy państwo polskie w realny sposób sprzyja kontaktom rodziców z dziećmi, czy też ogranicza te kontakty przez brak poprawy sytuacji ekonomicznej Polaków zmuszanych $\mathrm{w}$ ten sposób do wyjazdów za granicę w celu znalezienia pracy i utrzymania rodziny.

Kontakty, o których mowa, służą nie tylko rodzicom, ale - może ze względu na wiek rozwoju - przede wszystkim dziecku. Prawem dziecka w kontaktach z rodzicami jest również to, by było ono przez nich zabierane poza miejsce, w którym przebywa, by miało możliwość zmiany środowiska. Jeżeli jednak kontakty z dzieckiem ulegają pogorszeniu, charakteryzują się agresją wobec dziecka czy też innym niewłaściwym zachowaniem wobec niego, sąd ma prawo ograniczyć utrzymywanie tych kontaktów ${ }^{29}$, co stanowi ochronę dziecka przed negatywnym wpływem, jaki mogą wnieść w jego życie kontakty z rodzicem.

28 Ustawa z dnia 25 lutego 1964 r. Kodeks rodzinny i opiekuńczy (tj. Dz.U. z 2012 r., poz. 788 z późn. zm.).

29 Por. M. Andrzejewski, Prawo rodzinne i opiekuńcze, dz. cyt., s. 179. 


\section{Prawo do ochrony przed negatywnym wpływem otoczenia, szczególnie mass mediów}

Dziecku przysługuje również, ze względu na okres rozwoju, prawo do ochrony przed negatywnym wpływem otaczającej je rzeczywistości. Prawo to powinni realizować w pierwszej kolejności rodzice, ale także instytucje państwowe, w tym szkoła. Jednym z obszarów, w którym dziecko spotyka się z niewłaściwym oddziaływaniem na swoje życie, są media. Zadaniem dziennikarza jest służba odbiorcy ${ }^{30}$, nie zawsze jednak tak się dzieje, a najbardziej zagrożone negatywnym odbiorem medialnym są właśnie dzieci. Szczególne zadanie ochrony dzieci spoczywa na mediach publicznych, a wśród nich na TVP, która w swojej działalności ma zapisaną misyjność, a utrzymuje się między innymi z abonamentu ${ }^{31}$, właśnie po to, by ową misyjność zachować. Pobieranie opłat abonamentowych jest ważnym elementem, który powinien wpływać na ochronę odbiorcy, a szczególnie dziecka, przed niewłaściwymi treściami, mającymi charakter gorszący.

Istotnym zadaniem państwa w dziedzinie ochrony dzieci przed negatywnym wpływem środków społecznego przekazu jest budowanie odpowiedniego systemu szkolnictwa, który obejmie również edukację medialną uwrażliwiającą dziecko na zagrożenia, jakie mogą je spotkać ze strony mediów. Państwo jest również odpowiedzialne za odpowiednie treści w środkach społecznego przekazu. Nie chodzi tu bynajmniej o cenzurę, ale o niedopuszczanie audycji, filmów, bajek etc., które wpływałyby deprawująco na dziecko. Również rodzice powinni czuwać nad tym, jakie treści ogląda ich

30 Por. J. Sobczak, Prawo prasowe. Podręcznik akademicki, Warszawa 200o, S. 195 .

31 Por. K. Pokorna-Ignatowicz, Spór polityczny wokót Telewizji Polskiej, [w:] Media, władza, prawo, red. M. Magoska, Kraków 2005, s. 53. 
dziecko w telewizji, jakie strony przegląda w internecie. Istnieją metody blokowania stron internetowych czy też programów w telewizji, tak by dziecko nie miało do nich dostępu.

Należy pokrótce wskazać na konkretne zagrożenia, przed jakimi państwo i rodzina winny chronić dzieci. Chodzi tu między innymi o nadmierną brutalizację przekazu medialnego, epatującą przemocą, która może przekładać się na życie dziecka, jego zbyt silne podenerwowanie, niepokój, a nawet przemoc skierowaną wobec innych. Kolejnym istotnym problemem jest seksualizacja przekazu medialnego, którą można dostrzec już w teledyskach współczesnej muzyki pop. Należy podkreślić, że środki społecznego przekazu mają istotny wpływ na gusta i oczekiwania odbiorców ${ }^{32}$. Media ukierunkowane są na promocję zmysłowości, promocję poszukiwania satysfakcji seksualnej rozumianej w sposób „techniczny”, jednocześnie odrzucając miłość, która jest trwała i dojrzała33. Dlatego też tak ważne jest, by prawo regulowało dopuszczalność pewnych treści w mediach przy jednoczesnym zakazie promocji negatywnie wpływających na odbiorcę, szczególnie dziecko.

Polskie prawo zabrania rozpowszechniania treści, które zagrażają moralnemu, psychicznemu lub fizycznemu rozwojowi osób małoletnich, zwłaszcza jeżeli są to treści pornograficzne lub w sposób nieuzasadniony eksponujące przemoc ${ }^{34}$. Patrząc jednak na różnego rodzaju filmy czy audycje, można odnieść wrażenie, iż przywołany przepis Ustawy o radiofonii i telewizji nie jest skrupulatnie przestrzegany. Krajowa Rada Radiofonii i Telewizji monitoruje rynek

32 Por. A. Lepa, Pedagogika mass mediów, Łódź 1998, s. 53-55.

33 Por. M. Komorowska-Pudło, Seksualność młodzieży przełomu XX i XXI wieku, Kraków 2013, s. 125.

34 Por. Ustawa z dnia 29 grudnia 1992 r. o radiofonii i telewizji (Dz.U. 2004 r. $\mathrm{Nr}$ 253, poz. 2531 z późn. zm.), art. 18. 
mediów w Polsce, stąd też na tym konstytucyjnym organie ciąży obowiązek ochrony praw dziecka przed negatywnym wpływem przekazu medialnego będącego u źródeł współczesnych zagrożeń, z jakimi spotykają się dzieci.

\section{Zakończenie}

W powyższym artykule zostały nakreślone wybrane prawa dziecka. Aby istniał odpowiedni system prawny w danym państwie, aby system ten nie leżał u podstaw totalitaryzmu, musi w swoich zapisach odnosić się do godności osoby ludzkiej i wypływających z niej praw, także praw dziecka. Można by powiedzieć: szczególnie praw dziecka, gdyż to ono jest istotą często bezbronną, z racji swojego wieku pozbawioną odpowiedniego rozeznania rzeczywistości. W szczególny sposób prawo powinno chronić prawa dzieci poczętych, a nienarodzonych, począwszy od prawa do życia, a skończywszy na możliwości dziedziczenia.

Należy podkreślić, iż każde dziecko ma takie same prawa wypływające ze wspomnianej wcześniej godności, żadne prawo nie może zostać bezpodstawnie ograniczone ani żadne dziecko nie może być pozbawione swoich praw. Pierwszymi odpowiedzialnymi za to są ci, którzy stanowią prawo, a więc szeroko rozumiane państwo, następnie obowiązkiem rodziców jest stać na straży praw dziecka.

\section{SUMMARY}

\section{The rights of children in Polish law}

Some of the children's rights have been highlighted in the article. There has to be respect and dignity when a human being, and foremost a child, is considered, along with human rights. Furthermore, if a particular jurisprudence should function, so as not to be based on totalitarianism, there 
must be the respect and dignity of the abovementioned entities, i.e. adults and children. Foremost, children, as well as their rights, are the ones that are most vulnerable since the fact that such a small being could be harmed the easiest. Presumably since it is deprived of its ability to have a sufficient understandig of the surrounding world, and its apprehension of it, which, very often, is without complete comprehension. Therefore, children who were conceived, not only those given birth to, should be protected from the very start of their existence up to the moment of heredity.

It should be highlighted that each child possesses the very same rights, which, previously articulated, originate from respect and dignity. In addition, it must not be forgotten that their rights cannot be diminished at any lapse of conscience. Hence the first responsible are the ones who legislate the law.

Keywords: rights of children, human right, statutory law, constitutional law, civil law

Tomasz Kornecki, Prawa dziecka w prawie polskim - wybrane zagadnienia, [w:] Prawa dziecka: perspektywa Kościoła, red. ks. Piotr Kroczek, Kraków 2015, s. 63-80 (Annales Canonici Monographiae, 3). 